\title{
Augmented reality technology in the foreign language classroom in a non-linguistic university
}

\author{
Anastasia Isaeva $^{1 *}$, Galina Semenova ${ }^{1}$, Yana Nesterova $^{2}$, and Olga Gudkova ${ }^{2}$ \\ ${ }^{1}$ Tula State University, 300012, Tula, Russia \\ ${ }^{2}$ Tula State Lev Tolstoy Pedagogical University, 300026, Tula, Russia
}

\begin{abstract}
The article determines the necessity of using augmented reality technologies in the formation of professional foreign language competence of chemistry students of non-linguistic universities with the use of the methods of modeling of educational material, complementing it with visual and audio sequences, and developing students' skills of multifaceted projecting of situational reality. The goal of the study was to prove that, within the innovative educational augmented reality platform, the efficiency of the process of forming of the students' professional foreign language competence significantly increases. As part of the experimental work based on complex methods of research, such as: general theoretical methods (analysis, comparison, matching, generalization of the pedagogical, methodological, psychological, special literature, the implementation of the introduction of new augmented reality technologies); logical and comparative analytical methods (study of the accumulated the Russian and foreign experience in implementing of augmented reality technologies); empirical methods (survey, pedagogical experiment, observation, study and generalization of the advanced pedagogical experience, diagnostics, surveys, interviews, testing), - the effectiveness of using augmented reality technology during the formation of chemistry students' professional foreign language competence is proved: students' progress and understanding of the material improves, professional foreign language competence forms faster, the level of motivation increases, the degree of involvement in the learning process and interest in the subject increases, the level of communication between students grows.
\end{abstract}

\section{Introduction}

The global changes are taking place in the system of higher education in Russia towards the creation and distribution of a smart environment. It is obvious that traditional methods and models of education have exhausted their capabilities. The modern education system is forced to compete with the entertainment sphere, and therefore it requires such mechanisms of perception that can involve students in the process of acquiring new knowledge. It is

\footnotetext{
*Corresponding author: isaeva_anastasia91@mail.ru
} 
known that the effectiveness of training depends on interest, which must first be generated and then maintained. However, in the age of computer technology, it is not so easy to captivate the digital generation with drawings, watching old films or reading literature that is rapidly becoming obsolete. The main problem facing researchers today can be described as the inadequacy of traditional teaching methods in order to attract the attention of modern young people and provide effective learning.

All existing technologies of teaching the foreign language face one common problem to organize the student's educational activities in such a way as to create conditions for the development of internal motives [1]. The penetration of modern breakthrough information technologies into the field of higher education has enabled lecturers to qualitatively change the content, methods and organizational forms of education in various disciplines. The purpose of such technologies in education is to strengthen the intellectual abilities of students in the information society, to individualize and intensify the learning process and improve its quality $[2,3]$. Among the newest achievements that are used in the field of information technology, the so-called augmented reality (AR) systems have appeared. These systems are technologies that allow to combine images of real-world objects with various elements of computer graphics, as well as combine images obtained from different sources $[4,5,6,7]$. At the same time, AR systems involve embedding computer-generated objects into the surrounding reality, which is the main difference from virtual reality (VR) systems, which involve the use of an artificially created video sequence [8]. Currently used as devices: AR glasses, controllers, headphones, smartphones, tablets [4, 9, 10]. These devices allow a person to see and hear digital objects. In the near future, feedback gloves are expected, allowing a person to touch digital objects. In the last decade, thanks to the reduction in the cost of devices, such technologies have become more accessible to a wide range of users. The appearance of a personal digital device (laptop, tablet, or smartphone) for each participant in the educational process makes it possible at present to freely interact with the digital educational environment through the Internet during the lessons at university.

In most cases, the conservative orientation of the Russian educational system, its enduring formalism and the unwillingness of high school lecturers to use new technologies, hamper the development and use of many unique and useful technologies that could significantly speed up the cognitive process and improve the efficiency of education. However, in our opinion, in the modern world there is a great need for highly qualified specialists with knowledge of a professional foreign language, that is why the future of AR technologies has enormous prospects for the process of forming of professional foreign language competence of a non-linguistic university student. The relevance of the presented research is due to the rapid penetration of breakthrough information technologies not only into all spheres of life of students, but also into the system of higher foreign language education. The process of mastering the skills of professional foreign language communication in a non-linguistic university can be improved by using AR applications along with traditional teaching technologies.

Therefore, the goal of our study was to prove that, within the framework of the innovative educational AR platform, the efficiency of the process of forming of students' foreign language competence significantly increases.

To achieve the goal of our research, it was necessary to solve the following tasks:

- to expand the traditional methodology of foreign language teaching for students of nonlinguistic universities at the expense of the possibilities of AR programs by including the learner in the process of interaction with objects;

- to introduce the elements of an independent game into student's activity and the possibility of self-selection of objects (visually bright and three-dimensional moving models, corresponding to modern technical capabilities); 
- to carry out a comparative analysis of the level of the formation of foreign language competence of students, their level of motivation to learning, the degree of involvement in the learning process and interest in studying the subject, the level of foreign language communication between the students in groups using traditional forms of education and in groups using $\mathrm{AR}$ technologies.

The scientific novelty of the research is as follows:

- substantiated the possibility of using AR technology to increase the level of formation of professional foreign language competence of chemistry students of non-linguistic universities;

- for the first time, tested the use of mobile AR applications for studying chemistry in the process of teaching students a professional foreign language;

- experimentally proved the dependence of the levels of formation of students' foreign language competence, their level of motivation for learning, the degree of involvement in the learning process and interest in studying the subject, the level of foreign language communication between students from the use of AR technology in the educational process along with traditional forms of learning.

The solution to the tasks and test of the effectiveness of using AR technology during the formation of professional foreign language competence of chemistry students of a nonlinguistic university were carried out using complex methods of research, such as: general theoretical methods (analysis, comparison, matching, generalization of the pedagogical, methodological, psychological, special literature, the implementation of the introduction of new AR technologies); logical and comparative analytical methods (study of the accumulated the Russian and foreign experience in implementing of AR technologies); empirical methods (survey, pedagogical experiment, observation, study and generalization of the advanced pedagogical experience, diagnostics, surveys, interviews, testing).

These days experts, who focus on how cutting-edge technology can be used to add value to learning, see AR technology as an effective medium. Analyzing the works of foreign and domestic authors on this topic (M. Akçayır, G. Akçayır, H. Kaufmann, M. Papp, R. Kaiser, T. C. Huang, M. Y. Chen and W. P. Hsu, Yu.A. Kravchenko, A.A. Lezhebokov, S.V. Pashchenko, M.V. Yadrovskaya, A.V. Ivanova, I.A. Otkupshchikova, O.P. Kornienko, A.V. Dementyeva, K.N. Reskov, A.V. Grishkun, V.V. Grishkun, P.S. Bazhina, A.A. Kuprienko and etc.) it should be noted that the growing popularity of AR technology and interest in it is due to studies that substantiate the prospects of using AR technology in education. A huge number of AR applications allow you to diversify the teaching process of various disciplines in universities. However, in the formation of professional foreign language competence of students of a non-linguistic university, these technologies are rarely used [11].

In 1990s Thomas P. Caudell, a scientist at the Boeing Corporation, invented the concept and the idea of Augmented Reality (AR). In the future, the main definitions of AR technology, the features and possibilities of its application were considered in the works of R. Azuma, W. Chen, H. Kauffmann, P. Milgram, Yu.V. Sulimov, V.M. Kapatsyna, D.A. Kovalenko, etc.

$\mathrm{AR}$ is a technology for adding, introducing elements of virtual information into a person's real life. It allows to erase the line between the surrounding and artificially created world.

The idea of AR technology is relatively simple: it recognizes a given image of the real world (for example, GPS coordinates or an illustration from a textbook) and imposes an object of the virtual world (for example, an image, narration, etc.) on it [6, 7]. At the same time, it allows everyone to carry out interesting projects with it (for example, to enrich images in an ordinary paper textbook with multimedia content on a smartphone screen) [12]. As a result, an educational organization inevitably turns into an integrator of two 
environments where the complex of educational activities is planned and executed: physical (classrooms, laboratories, etc.) and virtual environment (hybrid cloud).

AR is used to "overlay" (combine) material objects and instructions for assembling and installing them (complex mechanisms and structures) [13] implementing control actions (dispatch services, remote interactive control, advanced reflection). The basic principle of operation of AR systems is the imposition of modes of "otherness" and the identification of real objects, allowing the user to "live in" an altered environment.

Today, AR complexes are widely used in various fields of human knowledge and practice. For example, in medicine, construction and engineering design, geo-information technologies, hydrometeorology, topography and mapmaking (GIS). Such technologies are used today in the creation of various high-realistic simulators. For example, for doctors it is an opportunity not only to attend but also to participate in a number of surgical operations; for military officers, pilots, sailors, firefighters and other representatives of extreme professions - "to participate" in the theaters of "real" military operations without leaving the cabinet (laboratory) and without suffering damage to manpower and technology [14].

AR technologies make learning more visual, allow to activate learners, to deeper engage them in the learning process. These technologies facilitate and simplify the collaboration of people who are at a distance. For example, students can meet with the help of AR tools, prepare joint presentations, execute projects and perform many other works almost as effectively as with personal contact in the real world. Teachers and students have the opportunity to use virtual laboratories for studying the world around them, developing and practicing skills, as well as for demonstrating their mastering and automated assessment. This type of training helps to increase engagement, communication between students and interest in the subject $[10,15]$. AR can encourage learners to participate actively in (co)constructing their learning environment, for example, by posting comments or questions relating to a particular location, uploading photos of their experiences, and so on. Because the technology assists in the moment, it can support "just-in-time" learning. In these ways, AR allows teachers to open up the classroom, provide remote assistance, and design activities that bridge formal and informal learning contexts. Recent studies have shown that learners appreciate the addition of a physical element to their learning and not having to be tied to one location [16].

Analysis of the applied services for working with AR helped to identify that nowadays one can download and install on the device a variety of simulator applications for learning the foreign language from the Internet. There is a great variety of them, the 10 most popular (TOP-10) simulators for teaching English are the following: 1) LinguaLeo, 2) Doulingo, 3) Words, 4) EasyTen, 5) BBC-Learning English, 6) LinQ, 7) Babbel, 8) English Grammar in Use, 9) English Pod, 10) Business English. Each of these applications has its own uniqueness and features and is a kind of AR technology which can be easily and effectively applied to the foreign language classes in a non-linguistic university [17]. According to K.V. Kapranchikova, mobile teaching of the foreign language as a specific form of organizing the learning and control process, the main condition of which is the active use of mobile devices (smartphones, tablet computers, etc.), allows students to develop and improve language skills, speech skills (based on the means of synchronous and asynchronous communication) anywhere and at any time, as well as to form socio-cultural and intercultural competence in order to use the foreign language as a means of communication in social and future professional spheres [18]. One way in which AR extends mobile technologies as it is mostly used at present is by involving the physical self in the interaction between virtuality and reality. Rather than engaging with resources at a cognitive level only, AR supports "embodied" and "extended" cognition, both of which emphasise the inextricable connection between the mind and the environment and "cognitive activity as grounded in bodily states and activities" [19]. M. Pu and Z. Zhong 
have created a mobile AR interaction game for English-vocabulary learning, named AR Magic English, and their empirical results suggest that the situational interaction gaming approach may significantly improve students' learning interest [20].

\section{Materials and Methods}

In order to achieve the goal of our study we tried to expand the traditional methodology of foreign language teaching for chemistry students of non-linguistic universities, due to the capabilities of AR programs, by including the student in the process of interaction with objects as well as made an attempt to introduce into student's activity the elements of an independent game and the possibility of independent selection of objects (visually bright and three-dimensional moving models that correspond to modern technical capabilities).

The groups of chemistry students studying at the Institute of Natural Sciences of Tula State University were involved to participate in the pedagogical experiment to identify the effectiveness of the process of forming professional foreign language competence of students as part of the innovative educational AR platform. The objects of activity of a graduate of specialty 020101 "Chemistry" are research and production organizations of the chemical and related profile, educational institutions, the service sector, economic and other institutions that require specialists with higher chemical education. The demand for graduates of the Department of Chemistry is obvious, since the Tula region is a region with a highly developed chemical industry. Among the largest enterprises of the region, it should be noted OJSC "Shchekinokhimvolokno", OJSC "Shchekinoazot", OJSC "Efremov Synthetic Rubber Plant", OJSC "Novomoskovskbytkhim", Novomoskovsk Azot NAK EuroChem, LLC "KNAUF GIPS NOVOMOSKOVSK", LLC "Aerosol and Novomoskovsk" and others. Development of small business leads to the opening of small enterprises specializing in the production of consumer goods, including chemical consumer goods, and for such enterprises that quickly respond to market needs, with a frequently changing range of products, chemistry specialists with basic education are required. In modern conditions of globalization, foreign language communication skills are becoming an essential component of the future professional activity of a young specialist. In recent years, young specialists with a good command of the foreign language have been in great demand in the labor market. The rapid development of international business contacts, the assimilation of the latest technologies, the creation of joint ventures, the intensification of professional activities in close contact with foreign specialists have significantly increased the importance of studying foreign languages in non-linguistic universities.

The empirical base of the pedagogical experiment was 63 students. During the experiment in 2018-2019 and 2019-2020 academic years it was attended by:

- 31 students (group 420481: 2 subgroups - experimental group № 1 and control group № $1)$;

- 32 students (group 420491: 2 subgroups - experimental group № 2 and control group № 2).

The experimental work was carried out as follows: the foreign language classes were conducted in the traditional way in the control groups. AR technology, along with traditional technologies, was used in the experimental groups. A distinctive feature of professionally oriented foreign language teaching for students of chemical specialties is the maximum consideration of the specifics of the professional sphere: its concepts and terminology, lexico-syntactic and grammatical features, the format of oral and written texts, situational features.

Students of the experimental and control groups studied professional vocabulary, read professional texts, prepared their own projects in the foreign language (for example, "Modem Uses of Oxygen", "The Bohr Theory of the Hydrogen Atom", "The Development 
of the Theory of Valence", "Waste disposal", "Innovations in chemical engineering", etc.), simulated the process of interaction with clients, employers, employees, partners (discussion of proposals, identification of project problems and their solution, possible project changes, etc.). All students mastered the same amount of material, they were allocated the same number of classroom hours.

In the experimental group, along with traditional teaching technologies, applications with “AR VR Molecules Editor", Chemistry AR applications, AR Notecards, etc. were used. Chemistry AR applications allow students to visualize and interact with the spatial structure of a molecule using a marker object in their hands. Using HP Reveal, a free app, you can create AR Notecards to study organic chemistry mechanisms or create virtual demonstrations of how to use laboratory instruments. With "AR VR Molecules Editor" application students can design single, double, and triple bond molecules and create cyclic models. By pointing the camera of a mobile device at a chemical formula printed on a piece of paper, the student will be able to observe and study a 3D representation of the corresponding molecule in AR. AR mode in the application is implemented based on the BYOD (Bring Your Own Device) approach [21, 22]. Students use their smartphones or tablets in class. The study of professional foreign language vocabulary was carried out using 3D visualization. Using $\mathrm{AR}$ as part of project assignments, students have the opportunity to visualize the results of work on their own or collective project, include all the necessary information - graphic, sound, video files in it and make it as interactive as possible, supplementing it with 3D graphics, and turn creative work into interactive performance. Students were interested in working with new technology, with new AR applications, everyone was maximally involved in the learning process.

Applying this technology in the foreign language classes for future chemists, we did not radically change the teaching methodology, but simply expanded the possibilities of a printed textbook. Visualization of objects has dramatically increased the attractiveness of the process of teaching a foreign language for a generation accustomed to the constant use of electronic devices since childhood.

At the end of the formative experiment, we compared the learning results in the control and experimental groups. The effectiveness of the process of forming professional foreign language competence of students in the framework of the innovative educational AR platform was examined on the basis of methods of questioning, testing, pedagogical observation and conversation.

\section{Results}

At the first stage of the experiment, there was an assessment of not only the actual initial level of the formation of foreign language competence of the students of the control and experimental groups, but also their level of motivation to learn, the degree, of involvement in the learning process and interest in studying the subject, the level of foreign language communication between students, which directly affect the process of forming foreign language competence. It was revealed that the dependent variables are indicators of the level of formation of foreign language competence (high - 13.6-14.5\%, average - 58.3$59 \%$, low $-26.9-27.8 \%$ ), the level of motivation to learning (high $-29.8-30.3 \%$, average $57.7-59 \%$, low $-11-12 \%$ ), the degree of involvement in the learning process and interest in studying the subject (high $-5,9-6.9 \%$, average $-22.9-24.5 \%$, low $-69.6-70.4 \%$ ), the level of foreign language communication between students (high $-3-3.7 \%$, average - 15.9$16.1 \%$, low $-80.4-80.8 \%$ ) among the students of the experimental and control groups are approximately the same.

The successful formation of professional foreign language competence is impossible without a high level of motivation for learning, the degree of involvement in the learning 
process and interest in studying the subject, the level of foreign language communication between students. There is a close relationship between the levels of motivation and interest and the quality of student's knowledge. Hence, it is a logical conclusion about the need to increase these levels. In order to find out how the use of the latest AR applications along with traditional technologies influenced the motivation of students and their interest in learning a professional foreign language, their involvement in the educational process, we decided to conduct conversations with students from the control and experimental groups.

Educational activities should be organized pedagogically and psychologically so as to constantly evoke and maintain a high level of motivation, i.e. stimulate the individual to the need to learn something new. Conversations with the students of the experimental groups revealed an increase in motivation for learning due to the organization of educational activities based on the visualization of professional objects, which made it possible to more carefully consider, study and discuss them at a professional level in the foreign language. Many respondents noted an increase in motivation to learn, as AR technology is adapted to the specific learning needs of each student. The use of AR applications in the foreign language classes, which provide the ability to regulate the volume and content of training depending on the needs of users, contributes to the emergence of students' need for selfactualization (the so-called motive of personal self-realization), which consists in a person's desire to "be what he can become" [23]. They provide each student with the opportunity to take an active cognitive position simultaneously with the teacher, i.e. he has a desire to continue cognitive activity beyond what is required, to pose problems on his own, to establish patterns. Many students find it interesting to participate in the foreign language space.

One of the best methods for diagnosing success motivation and failure fear motivation is pedagogical observation. The ability to follow the behavior and activities of students in various educational situations and subject their observations of the personality, activities and behavior of the student to a thoughtful and deep psychological analysis using AR technology made it possible to conclude that AR transforms the roles of teachers and students, helps to overcome constraint, language barrier, and change the type of fear of failure motivation to success motivation. In the control group with traditional forms of education, these changes are less noticeable. A comparative analysis of the research data on the level of formation of motivation for teaching students in the control and experimental groups is presented in Table 1.

Table 1. Comparative analysis of the level of learning motivation of the students of the control and experimental groups

\begin{tabular}{|c|c|c|c|c|c|c|}
\hline \multirow{2}{*}{ Group } & \multicolumn{3}{|c|}{$\begin{array}{c}\text { At the beginning of the } \\
\text { experiment }\end{array}$} & \multicolumn{3}{c|}{ At the end of the experiment } \\
\cline { 2 - 7 } & $\begin{array}{c}\text { low } \\
\text { level, \% }\end{array}$ & $\begin{array}{c}\text { average } \\
\text { level, \% }\end{array}$ & $\begin{array}{c}\text { high } \\
\text { level, \% }\end{array}$ & $\begin{array}{c}\text { low } \\
\text { level, \% }\end{array}$ & $\begin{array}{c}\text { average } \\
\text { level, \% }\end{array}$ & $\begin{array}{c}\text { high } \\
\text { level, \% }\end{array}$ \\
\hline Control group 1 & 31.1 & 58.7 & 10.2 & 9 & 58.1 & 32.9 \\
\hline Control group 2 & 30.7 & 59.2 & 10.1 & 8 & 60.3 & 31.7 \\
\hline $\begin{array}{c}\text { Experimental } \\
\text { group 1 }\end{array}$ & 31.2 & 59 & 9.8 & 2.2 & 56.8 & 42 \\
\hline $\begin{array}{c}\text { Experimental } \\
\text { group 2 }\end{array}$ & 31.6 & 58.1 & 10.3 & 2.7 & 53.6 & 43.7 \\
\hline
\end{tabular}

Diagnostics of the degree of involvement in the learning process and interest in studying the subject and the level of foreign language communication between students among the students of the control and experimental groups was carried out using the methods of questioning and pedagogical observation. Interest is formed and develops in activity, and it 
is influenced not by individual components of the activity, but by its entire objectivesubjective essence (character, process, result). Absorption in activity, disconnection from external stimuli, positive emotions of confidence in one's abilities, a stable optimistic inner mood are more characteristic when using AR technology in the foreign language classes for students of the experimental groups. We assessed and compared the degree of involvement in the learning process and interest in studying the subject and the level of foreign language communication between students among students of the control and experimental groups at the beginning of the ascertaining and the end of the formative experiments. The effectiveness of using AR technologies to increase the studied criteria in the experimental groups is confirmed by the dynamics of their development. A comparative analysis of the degree of involvement in the learning process and interest in the study of the subject and the level of foreign language communication between students among the students of the control and experimental groups is presented in Tables 2 and 3.

Table 2. Comparative analysis of the degree of involvement in the learning process and interest in studying the subject of the students of the control and experimental groups

\begin{tabular}{|c|c|c|c|c|c|c|}
\hline \multirow{2}{*}{ Group } & \multicolumn{3}{|c|}{$\begin{array}{c}\text { At the beginning of the } \\
\text { experiment }\end{array}$} & \multicolumn{2}{c|}{ At the end of the experiment } \\
\cline { 2 - 7 } & $\begin{array}{c}\text { low } \\
\text { degree, } \\
\%\end{array}$ & $\begin{array}{c}\text { average } \\
\text { degree, } \\
\%\end{array}$ & $\begin{array}{c}\text { high } \\
\text { degree, } \\
\%\end{array}$ & $\begin{array}{c}\text { low } \\
\text { degree, } \\
\%\end{array}$ & $\begin{array}{c}\text { average } \\
\text { degree, } \\
\%\end{array}$ & $\begin{array}{c}\text { high } \\
\text { degree, } \\
\%\end{array}$ \\
\hline Control group 1 & 69.9 & 23.2 & 6.9 & 57.1 & 35.1 & 7.8 \\
\hline Control group 2 & 70.1 & 23.7 & 6.2 & 56.6 & 35.3 & 8.1 \\
\hline $\begin{array}{c}\text { Experimental } \\
\text { group 1 }\end{array}$ & 69.6 & 24.5 & 5.9 & 23.8 & 53.9 & 22.3 \\
\hline $\begin{array}{c}\text { Experimental } \\
\text { group 2 }\end{array}$ & 70.4 & 22.9 & 6.7 & 22.1 & 54 & 23.9 \\
\hline
\end{tabular}

Table 3. Comparative analysis of the level of foreign language communication between students among the students of the control and experimental groups

\begin{tabular}{|c|c|c|c|c|c|c|}
\hline \multirow{2}{*}{ Group } & \multicolumn{3}{|c|}{$\begin{array}{c}\text { At the beginning of the } \\
\text { experiment }\end{array}$} & \multicolumn{2}{c|}{ At the end of the experiment } \\
\cline { 2 - 7 } & $\begin{array}{c}\text { low } \\
\text { level, } \\
\%\end{array}$ & $\begin{array}{c}\text { average } \\
\text { level, \% }\end{array}$ & $\begin{array}{c}\text { high } \\
\text { level, } \\
\%\end{array}$ & $\begin{array}{c}\text { low } \\
\text { level, } \\
\%\end{array}$ & $\begin{array}{c}\text { average } \\
\text { level, \% }\end{array}$ & $\begin{array}{c}\text { high } \\
\text { level, } \%\end{array}$ \\
\hline Control group 1 & 80.8 & 16.1 & 3.1 & 71.1 & 24.3 & 4.6 \\
\hline Control group 2 & 80.8 & 16.2 & 3 & 71.8 & 23.7 & 4.5 \\
\hline $\begin{array}{c}\text { Experimental } \\
\text { group 1 }\end{array}$ & 80.5 & 16 & 3.5 & 35.6 & 47.9 & 16.5 \\
\hline $\begin{array}{c}\text { Experimental } \\
\text { group 2 }\end{array}$ & 80.4 & 15.9 & 3.7 & 36.1 & 48 & 15.9 \\
\hline
\end{tabular}

The level of formation of professional foreign language competence of the students of the control and experimental groups was checked using testing. Testing consisted of various tasks to check the formation of skills in four types of speech activity: reading, writing, listening and speaking. In the control group, the indicators increased significantly less than in the experimental group. Visibility, informational completeness and interactivity, developing in the trainees figurative thinking and spatial imagination, allow them to "get used to" the professional foreign language environment by including the trainee in the process of interaction with objects. $3 \mathrm{D}$ visualization of objects makes it possible to more productively master the foreign language terminology of the specialty. The test results at 
the beginning of the ascertaining and the end of the formative experiments are presented in Table 4.

Table 4. Comparative analysis of research data on the level of formation of professional foreign language competence of the students of the control and experimental groups

\begin{tabular}{|c|c|c|c|c|c|c|}
\hline \multirow{2}{*}{ Group } & \multicolumn{3}{|c|}{$\begin{array}{c}\text { At the beginning of the } \\
\text { experiment }\end{array}$} & \multicolumn{3}{c|}{$\begin{array}{c}\text { At the end of the } \\
\text { experiment }\end{array}$} \\
\cline { 2 - 7 } & $\begin{array}{c}\text { low } \\
\text { level, } \\
\%\end{array}$ & $\begin{array}{c}\text { average } \\
\text { level, \% }\end{array}$ & $\begin{array}{c}\text { high } \\
\text { level, } \\
\%\end{array}$ & $\begin{array}{c}\text { low } \\
\text { level, } \\
\%\end{array}$ & $\begin{array}{c}\text { average } \\
\text { level, \% }\end{array}$ & $\begin{array}{c}\text { high } \\
\text { level, } \%\end{array}$ \\
\hline Control group 1 & 27.8 & 58.3 & 13.9 & 21.4 & 62.2 & 16.4 \\
\hline Control group 2 & 26.9 & 59 & 14.1 & 20.7 & 63.1 & 16.2 \\
\hline $\begin{array}{c}\text { Experimental } \\
\text { group 1 }\end{array}$ & 27.2 & 58.3 & 14.5 & 7.1 & 56.8 & 36.1 \\
\hline $\begin{array}{c}\text { Experimental } \\
\text { group 2 }\end{array}$ & 27.7 & 58.7 & 13.6 & 6.4 & 58.7 & 34.9 \\
\hline
\end{tabular}

\section{Discussion}

This research has experimentally confirmed that the use of AR technology in the process of forming the professional foreign language competence of a non-linguistic university student:

1) enriches visual and contextual learning of the foreign language;

2) improves the pithiness of foreign language information $(80 \%$ of it is retained in shortterm memory compared with $25 \%$ when listening (traditional lessons) or reading the text);

3) does not require a fundamental change in the methodology of foreign language teaching, i.e. we simply expand the capabilities of the textbook;

4) dramatically increases the attractiveness of the process of learning of the foreign language for the generation who have become accustomed to the constant use of electronic devices since childhood;

5) activates the cognitive activity of students;

6) makes the foreign language classes more informative;

7) increases the motivation of students to learn a professional foreign language.

Students who can communicate face to face in a real foreign language environment, represented by AR, have the opportunity to share their knowledge and experience within the group. AR provides a flexible learning environment for students while enabling them to interact, interpret, solve problems, and improve their creative thinking skills. With AR applications that provide a realistic simulation and testing environment for the student by bringing computer applications into the real world, the learning and teaching process becomes more interactive, influential and powerful, as well as enjoyable while learning. All these facts testify to the educational benefits of AR technology.

The experiment was conducted in a non-language University and was based on using the applications with "AR VR Molecules Editor", Chemistry AR applications, AR Notecards, etc. for chemistry students. However, there are many other AR applications that are not directly intended for learning a foreign professional language, but that can be used for this purpose as well. Using AR technology in the foreign language classes in a nonlinguistic university, future physicists, biologists, technologists, builders, physicians, chemists, architects and other specialists have a unique opportunity in the age of breakthrough information technologies to learn professional foreign language vocabulary by viewing and interacting with $3 \mathrm{D}$ models of the objects and even changing them, for 
example, in the automotive industry it is a three-dimensional model of a car, in construction - a three-dimensional model of a building, in medicine - a three-dimensional model of human cells, in chemistry - a three-dimensional model of a chemical element, in physics a visualization of the equations of mathematical physics, etc. AR imposes the content directly on the camera, usually via a smartphone, tablet, netbook, or headset $[4,9,10]$. Using the possibilities of AR in the foreign language classes gives a unique opportunity to visually reproduce processes that are difficult or almost impossible to reproduce with the means of the real world and simply make the learning process fascinating and understandable, for example, to make virtual trips using Expeditions and Cardboard. AR can add expressive animations to the static pages of a textbook and newspapers, booklets, magazines, geographical maps and others. It can turn reading and translation into an exciting game and an interesting adventure along with the heroes of famous works while seriously and thoroughly practicing professional vocabulary, as well as simplify the playback of audio and video content offered to the paper book [24]. Educational games, learning applications, visual modeling of objects, various applications for training skills all these can be effectively used in the formation of professional foreign language competence of students.

\section{Conclusions}

The conducted research allowed us to draw the following conclusions:

1) AR technology is a high-precision, energy-saving, interactive technology that guarantees the achievement of specific pedagogical goals;

2) AR technology successfully engages students in the process of forming professional foreign language competence and motivates learning;

3) the process of forming professional foreign language competence of students proceeds more effectively within the framework of the innovative educational AR platform.

The acceleration and complication of the development of society forces us to look for new effective ways of organizing educational and cognitive activity in higher education. How to maximize the effective provision of students with the necessary professional foreign language competence? The study provides an unequivocal answer: one of the most promising technologies to solve this issue is AR technology. It is these modern interactive technologies that bring into the learning process bright three-dimensional images, a game element, intensify the interaction of participants in the educational process developing spatial thinking and skills of project activities [25]. The introduction of an innovative educational platform of AR in the process of teaching a foreign language at a university is a real way of moving forward, not only because we live in the age of information technology, but because AR technology is one of the most effective ways of learning the subject environment and space around us. Thanks to AR, students have endless opportunities for learning new things.

We see prospects for further study of the problem in a more detailed study of existing AR applications and their implementation in the process of foreign language training of future specialists. Research in this direction can be continued and expanded. In the future, it would be interesting to study separate printed textbooks for students of non-linguistic universities with AR applications.

The results of the study can be used by teachers of a foreign language in the preparation and conduct of classes in groups of students of non-linguistic universities at all stages of education.

\section{References}


1. O.V. Varnikova, Formation of professional competence of students of higher education in the process of foreign language training, $\mathrm{PhD}$ Thesis, (2011).

2. T.H.C. Chiang, S.J.H. Yang, G.J. Hwang, Journal of Educational Technology and Society 17 (4), 352-365 (2014).

3. A. Statti, K.M. Torres, Second or Foreign Language Learning with Augmented Reality, Augmented Reality for Enhanced Learning Environments, edited by Gerardo Reyes Ruiz and Marisol Hernández Hernández, IGI Global. pp. 193-221 (2018). DOI: http://doi:10.4018/978-1-5225-5243-7.ch008

4. M. Akçayır, G. Akçayır, Educational Research Review 20, 1-11 (2017).

5. R.D.A. Budiman, Journal of Education 1 (2), 89-94 (2016).

6. B. Redondo, R. Cózar-Gutiérrez, J.A. González-Calero, Early Childhood Education Journal 48, 147-155 (2020). DOI: https://doi.org/10.1007/s10643-019-00999-5

7. J.M. Sáez-López, R. Cózar-Gutiérrez, M.C. Domínguez-Garrido, Digital Education Review 34, 59-75 (2018). DOI: https://doi.org/10.1344/ der.2018.34

8. M. Popolo, The 9 Best Virtual Reality Headsets of 2020 (2019). https://www.lifewire.com/best-virtual-reality-headsets-4060322 last accessed 2021/02/11.

9. Z. Syarifudina, Astes Journal 5 (2), 774-780 (2020). DOI: 10.25046/aj050297

10. X. Wei, D. Weng, Y. Liu, Y. Wang, Computers and Education 81, 221-234 (2015).

11. G.V. Semenova, Pedagogika. Voprosi teorii i praktiki 5 (1), 128-133 (2020). http://dx.doi.org/10.30853/pedagogy.2020.1.23 last accessed 2021/01/11.

12. A.Yu. Uvarov, Nauka i shkola 4, 108-117 (2018).

13. S.J. Henderson, S. Feine, Evaluating the Benefits of Augmented Reality for Task Localization in Maintenance of an Armored Personnel Carrier Turret, Proceeding of IEEE International Symposium on Mixed and Augmented Reality 135-144 (2009).

14. N.S. Antonova, R.B. Yakovleva, The use of cognitive practices of constructing augmented reality in the methods of foreign language teaching in high school classes, Inostrannie yaziki: problemi prepodavaniya i riski kommunikatsii. Nauchnie issledovaniya studentov fakul'teta inostrannikh yazikov i lingvodidaktiki SGU imeni N.G. Chernishevskogo, 9-13 (2017).

15. D. Sahin, R.M. Yilmaz, Computers \& Education, 103710 (2020). DOI: https://doi.org/10.1016/j.compedu.2019.103710.

16. R. Lindgren, M. Johnson-Glenberg, Educational Researcher 42 (8), 445-452 (2013). http://dx.doi.org/10.3102/0013189X13511661 last accessed 2020/20/12.

17. G.V. Semenova, A.Yu. Isaeva, Mir nauki. Pedagogika i psihologiya 8 (1) (2020). https://mir-nauki.com/52PDMN120.html last accessed 2021/10/02.

18. K.V. Kaprantschikova, Methodology of teaching a foreign language to students on the basis of mobile technologies (English, the direction of training "Jurisprudence"). $\mathrm{PhD}$ Thesis, (2014).

19. D. Atkinson, Applied Linguistics $31 \quad$ (5), 599-622 (2010). http://dx.doi.org/10.1093/applin/amq009 last accessed 2020/25/12.

20. M. Pu, Z. Zhong, Development of a situational interaction game for improving preschool children' performance in English vocabulary learning, Proceedings of the 2018 international conference on distance education and learning (New York, ACM,2018) pp. 88-92. DOI: https://doi.org/10.1145/3231848.3231851 
21. A.A. Paskova, Vestnik Maykopskogo gosudarstvennogo technologicheskogo universiteta 4, 98-105 (2018).

22. S. Wilden, Mobile learning (Oxford University Press., 2017).

23. G.V. Semenova, Modular approach to the design and implementation of a curriculum for the development of additional qualifications "Teacher" (PhD Thesis, 2006).

24. K.V. Cherkasov, N.S. Chistyakova, V.V. Chernov, Problmi pedagogiki 1 (24), 40-41 (2017).

25. Yu.F. Katkhanova, K.I. Bestybaeva, Pedagogicheskoe masterstvo i pedagogicheskie technologii 2 (8), 289-291 (2016). 